\title{
The Determinants of the Capital Structure: An Applied Study on SMEs in the City of Meknes- Morocco
}

\begin{abstract}
By Mohamed Oudgou*
This article aims to present the determinants of the debt of Small and Mediumsized Enterprises' (SMEs') in the city of Meknes. To test the research hypothesis, a sample of 47 non-listed SMEs has been compiled and a static multiple regression model is developed. The result of the regression obtained indicates that size, profitability, and risk negatively influence the SMEs' debt. Whilst profitability and commercial debt are positively associated with debt. Industrial SMEs' use more debt compared to commercial SMEs'.
\end{abstract}

Keywords: debt, financial structure, SMEs', OLS regression

\section{Introduction}

The role of SMEs in economic and social development is strongly recognized in several academic and institutional studies (OECD 2007, St-Pierre 2004, Torres, 2004). They account for about $90 \%$ of all enterprises in each country and generate more than 50\% of GDP (OECD 2002, 2007). The importance of SMEs in the Moroccan economy is statistically significant. However, these enterprises face prohibitive internal and external handicaps, wherein the recourse to debt has been the most confronted difficulties. This problem makes SMEs focus on survival instead of innovation. However, even though the public authorities are aware of the importance of SMEs and have made considerable efforts, SME recourse to debt remains a persistent problem. Solving the problem of SME financing will certainly be a major challenge, a major development issue for the country. This encourages all stakeholders (institutions and researchers) to develop objective diagnoses to identify the real obstacles and propose solutions that will enable SMEs to get started and to play a main role in the economy.

In this present paper, we focus on the determinants that are relevant to SMEs in explaining their propensity to use debt. Indeed, while several empirical studies have attempted to explain the financial structure of SMEs, there is still no consensus on the determinants of debt (Colot and Croquet 2007). In the Moroccan context, there is still a substantial lack of studies on the subject, which leaves enough ambiguities in the financial characteristics of SMEs. On this basis, the present paper intends to contribute to the knowledge of scientists' work on the determinants of indebtedness of Moroccan SMEs.

\footnotetext{
*Professor, National School of Business and Management, Sultan Moulay Slimane UniversityBeni-Mellal, Morocco.
} 
The literature review of the financial structure is based on the founding article of Miller and Modigliani (1958). Under a restrictive assumption (perfect market without taxes, transaction costs, and bankruptcy costs) Miller and Modigliani (1958) confirm that the value of the firm is independent of the type of financing (debt or equity). Moreover, the financial structure does not affect investment decisions, and it is irrelevant to determining the value of a firm. In a second model, Miller and Modigliani (1963) take into account the tax-deductibility of interest. They concluded that firms preferred debt over other sources of financing because the interest payments are a deductible tax. This positive impact affects the market value of the business. This means that the company value is positively correlated with debt.

The questioning assumption that there is no conflict between shareholders and managers has given rise to the agency theory (Jensen and Meckling 1976). According to this theory, indebtedness minimizes agency conflicts between shareholders and executives. Nonetheless, it can create conflicts between the company and its lenders because of the existence of informational asymmetries in the relationship of financing.

To limit these conflicts of interest, lenders often introduce restrictive clauses in the debt contract. The purpose of these mechanisms is to encourage the borrowing firm to meet its commitments and reduce the risk of asset substitution (Besanko and Thakor 1987). Under these conditions, the optimal financial structure results, according to the arbitrage theory, from the trade-off between the advantage generated by indebtedness and the bankruptcy costs generated by over debt. Besides, the debt can be used as a signaling tool for the quality of the company in an environment characterized by asymmetric information (Leland and Pyle 1977, Ross 1977). A strong asymmetry of information can lead firms to make a massive use of internal financing resources, if necessary, calling on debt before increasing capital (Myers and Majluf 1984).

Referring to the empirical review, we find that there is no theoretical framework that encompasses all the theories and from which the explanatory variables for the financial structure of SMEs would be determined. As a result, the question of the application and relevance of the financial theory in explaining the indebtedness of SMEs is still partially validated. Table 1 illustrates the main factors explaining the corporate debt found in the Moroccan empirical literature.

Table 1. The Main Factors Explaining the Debt

\begin{tabular}{|l|c|l|}
\hline Variables & $\begin{array}{c}\text { Effect on } \\
\text { debt }\end{array}$ & \multicolumn{1}{c|}{ Author(s) } \\
\hline \multirow{3}{*}{ Size } & Positive & $\begin{array}{l}\text { (Hakmaoui and Yerrou 2013), (Achy and Rigar 2005), } \\
\text { (Amraoui et al. 2018), (Kartobi 2013), (Rahj 2016) }\end{array}$ \\
\cline { 2 - 3 } & Negative & (Achy and Rigar 2005), (Oudgou and Zeamari 2018) \\
\hline \multirow{2}{*}{ ROE } & Positive & (Oudgou and Zeamari 2018) \\
\cline { 2 - 3 } & Negative & $\begin{array}{l}\text { (Rafiki 2008), (Amraoui and al. 2018), (Messaoudi and } \\
\text { Binkkour 2016) }\end{array}$ \\
\hline \multirow{2}{*}{ ROA } & Positive & (Hakmaoui and Yerrou 2013) \\
\cline { 2 - 3 } & Negative & $\begin{array}{l}\text { (Amraoui et al. 2018), (Kartobi 2013), (Rahj 2016), } \\
\text { (Oudgou and Zeamari 2018) }\end{array}$ \\
\hline
\end{tabular}




\begin{tabular}{|l|c|l|}
\hline \multirow{3}{*}{ Tangibility } & Positive & (Hakmaoui and Yerrou 2013), (Kartobi 2013) \\
\cline { 2 - 3 } & Negative & $\begin{array}{l}\text { (Yerrou and Hakmaoui n.d.), (Achy and Rigar 2005), } \\
\text { (Amraoui et al. 2018), (Kartobi 2013) }\end{array}$ \\
\hline \multirow{2}{*}{ Growth } & Positive & (Rafiki 2008) \\
\cline { 2 - 3 } & Negative & $\begin{array}{l}\text { (Messaoudi and Binkkour 2016), (Dine-dine and El- } \\
\text { Khamlichi 2017) }\end{array}$ \\
\hline \multirow{2}{*}{ Risk } & Positive & Kartobi (2013) \\
\cline { 2 - 3 } & Negative & $\begin{array}{l}\text { (Hakmaoui and Yerrou 2013), (Yerrou and Hakmaoui n.d.), } \\
\text { (Oudgou and Zeamari 2018) }\end{array}$ \\
\hline
\end{tabular}

The main determinants of indebtedness derived from the financial theory and encountered in empirical work are generally contradictory. Whereupon, there is no consensus on these determinants. The current paper will, therefore, attempt to formulate the hypotheses while referring to the main variables encountered in previous empirical works.

\section{Hypotheses and Variables}

\section{The Dependent Variable}

The dependent variable to be explained is the total debt ratio (END). This ratio reflects the financial policy pursued by a firm (Drobetz and Fix 2003), and it is a pertinent indicator for assessing the risk of bankruptcy of a borrowing firm (Rajan and Zingales 1995). The study will adopt the measure used by Zou and Xiao (2006), Gaud and Jani (2002), Drobetz and Fix (2003), Kremp and Stöss (2001):

Total debt $(E N D)=$ Total liabilities/balance sheet total .

\section{Independent Variables}

The size (TAL): the size does not refer to a specific theory, but it is a matter of doctrine in empirical studies of debt. This variable assesses the solvency and the quality information produced and published by SMEs. The size is, therefore, a proxy for asymmetric information and financial constraints. In fact, the problems of information production and disclosure are more significant among SMEs. These problems render SME more opaque and unable to get access to debt (Ang 1992, Beck and Demirguc-Kunt 2006, Achy and Rigar 2005). We retain the size measure often used in empirical studies, especially by De Jong andVeld (2001), Chen (2004), Chen et al. (2014), Fakhfakh and Atitallah (2006), Zou and Xiao (2006): $T A L=\log$ (total assets).

\section{Hypothesis 1: Size has a Negative Impact on the Debt Ratio of SMEs}

Profitability (ROA): According to the signal theory and static equilibrium theory, high profitability has a positive influence on the debt ratio since the firm 
can take advantage of the interest deductibility (Bourdieu and Colin-Sédillot 1993). High profitability is also a signal of the sound financial health of the company. However, profitability, according to the Pecking Order Theory, is an indicator of cash financing which affects negatively the debt of asymmetrical companies (Fama and French 1999, Rajan and Zingales 1995, Wessels 2009).

SMEs are opaque and they consider debt more expensive and, therefore, prefers equity. As proclaimed by Benkraiem (2010), Colot and Croquet (2007), the profitability measured by the ratios: $R O A=$ net income/total assets.

Hypothesis 2: A Negative Effect of Profitability on the Debt Ratio of SMEs is Expected

Return on equity (ROE): According to the Trade-Off Theory, financial profitability is a guarantee for creditors of the companies' ability to repay debts. This is a positive signal of the company's financial health in accordance with the signal theory. Consequently, a sustained improvement in profitability should lead to an increase in debt. Drawing upon this theory, profitable companies with a low risk of financial failure would use debt to benefit from the interest deductibility. This theoretical framework predicts a positive relationship between debt and financial profitability. As advocated by Colot and Croquet (2007) and Rafiki (2008), we use the ratio of: $R O E=$ net income/ equity.

\section{Hypothesis 3: Financially Profitable SMEs Offer More Security to Creditors and Make Greater Use of Debt}

Growth (CRO): a high growth rate is synonymous with self-financing capacity, but it leads to a deterioration in the level of the company's working capital need. The agency theory contends that high-growth firms tend to have a less debt ratio. Whereupon, high growth tends to reconcile the interests of managers and shareholders (Kooyul et al. 1996). As a result, debt agency costs are high (Jensen and Meckling 1976, Myers 1977) and debt can no longer play its role as a regulator to the opportunistic behavior of managers. According to the Pecking Order Theory, companies with growth opportunities to finance turn first to external debt, which is less subject to asymmetric information. For the Compromise Theory, high-growth companies have incentives to increase their debt to take advantage of the interest tax deductibility. Growth estimates differ among major studies, the indicator used in this article is the asset growth rate (CRO): = $\frac{T A_{n}-T A_{n-1}}{T A_{n-1}}$

\section{Hypothesis 4: A Negative Effect of the Growth Rate on Debt is Expected}

Risk (RSQ): Risk consists of two components: financial risk and economic risk. The first is the overuse of debt. The second is due to the volatility of operational/net income (Dubois 1987). According to the trade-off theory, high volatility of operating income deprives the firm of the benefit of tax-deductibility of debt costs. In the context of the Pecking Order theory, earnings volatility may 
lead firms to build up a reserve of easily liquid assets so as not to face the problem of under-investment in the future. High volatility in operating results may lead the company to default so that lenders demand a high-interest rate. This suggests a negative relationship between risk and the debt ratio, which has been proved in several empirical studies (Prowse 1990, Jarrell and Kim 1984, Gaud and Jani 2002). Conversely, Kremp and Stoss (2001) predict a positive relationship between risk and debt. This can explain the presence of an over-investment strategy concealed by the firm from lenders. Risk will, therefore, be measured by the absolute value of the change in profits between $\mathrm{t}$ and $\mathrm{t}-1: R S Q=\frac{R_{t}-R_{t-1}}{R_{t-1}}$.

\section{Hypothesis 5: Earnings Volatility is Negatively Correlated with Debt Ratio}

Asset tangibility (TAG): tangible assets lose less value over usage or over time and are less subject to information asymmetries. For the agency theory (Jensen and Meckling 1976), the existence of a large share of tangible assets is an important guarantee for lenders faced with problems of over-investment. This can also reduce the agency external costs. For the theory of hierarchical financing, firms with a low share of tangible fixed assets in their assets will be exposed to information asymmetries (Harris and Raviv 1991).Empirical work by Frank and Goyal (2003), Bourdieu and Colin (1993), Gaud and Jani (2002), Rajan et al. (2000) and Rajan and Zingales (1995) found a positive effect of tangible or collateral assets on debt. Some works have found a negative effect (Achy and Rigar 2005, Amraoui et al. 2018, Kartobi 2013). Asset tangibility is measured by the ratio of net tangible assets (AC) augmented by stocks (S) to total assets (TA) (Adair and Adaskou 2011, Kremp and Stöss 2001, Rafiki 2008): $T A G=\frac{A C+S}{T A}$

\section{Hypothesis 6: Total Debt should be Positively Correlated with Asset Tangibility}

Taxes (FIS): According to the work of Modigliani and Miller (1963), to maximize their value, it is in the interest of firms to increase their indebtedness to take advantage of the tax-deductibility of debt costs. The Trade-off theory (TradeOff Theory) suggests that an optimal debt-to-income ratio could be achieved by balancing the marginal benefits and costs of indebtedness (the tax savings and bankruptcy costs associated with a high debt-to-income ratio) (Baxter 1967). On the other hand, the presence of non-debt related tax benefits reduces the attractiveness of debt. Many considerations may explain this limitation of debt. In Morocco, a large proportion of companies avoid paying income tax for various reasons: nearly $80 \%$ of corporate taxes are paid by $0.98 \%$ of companies in 2018 . This can explain not only the existence of tax advantages that are not linked to indebtedness, but also the asymmetric nature of Moroccan SMEs. 
Hypothesis 7: The Attractiveness of Debt for SMEs is made Less Attractive by the Presence of Income Tax

Commercial debt (DFR): according to the compromise theory, the use of commercial debt can be interpreted by the bank as a signal of the company's ability to repay its debts. Therefore, SMEs can easily have access to debt. On the contrary, Petersen and Rajan (1994) consider commercial debt as a substitute for financial debt in situations of credit rationing. The Pecking Order Theory considers commercial debt as a less risky means of short-term financing for small firms.

\section{Hypothesis 8: An Increase in Commercial Debt Reduces Interest on Debt Financing}

The business sector (SCT): The business sector is an important indicator of the type of capital structure and debt decision. Firms in the service and retail sectors make little use of debt since they do not have enough assets to present as collateral to banks. Conversely, firms in the industrial sector are characterized by a rigid asset structure and have easy access to bank credit (Riding et al. 1994). Margaritis and Psillaki (2010) consider the business sector as an indicator of the risk of the firm's core business. The sector of activity is a dummy variable, taking 1 if the firm is industrial, and 0 if it is retail.

Hypothesis 9: Industrial SMEs are more Indebted than Commercial SMEs

\section{Data}

This section is devoted to describe the research methodology as well as presenting the data collection procedures.

\section{Data Collection}

The accounting data required for the empirical study are collected from three trustees based in Meknes city and accredited by the National Order of Chartered Accountants. The data dated back to 2015 and were obtained after their official deposit at the General Taxes Directorate in Meknes city in 2016.

The first sample consists of 53 SMEs that correspond to the definition of Morocco-SME Agency (an SME is an enterprise with an annual turnover of less than 175 million MAD). For the sake of homogeneity, we kept only 47 companies after the elimination summary statement with incomplete financial information. We found that the largest number of SMEs do not have long-term financing debts. The availability of trade debts and very short-term bank debts in the liabilities part of their balance sheets was enough to keep them for the empirical study. 


\section{Econometric Model}

To attain our research objective, we perform the following regressions equation to find the impact of exogenous variables on the total SMEs debt (Table 2 ). The empirical specification of the model as shown in equation below, is estimated by ordinary least square (OLS):

$$
\begin{aligned}
E N D_{i}=C & +\beta_{1} T A I L+\beta_{2} R O A+\beta_{3} R O E+\beta_{4} R S Q+\beta_{5} C R O+\beta_{6} T A G \\
& +\beta_{7} F I S+\beta_{8} D F R+\beta_{9} S C T+\varepsilon
\end{aligned}
$$

Table 2. Variables and Expected Signs

\begin{tabular}{|l|c|c|c|}
\hline Variables & Acronym & Formula & $\begin{array}{c}\text { Expected } \\
\text { sign }\end{array}$ \\
\hline Total debt & END & Total liabilities /balance sheet total & $* * *$ \\
\hline Profitability & ROA & net income/total assets & - \\
\hline Return on equity & ROE & net income / equity & + \\
\hline Assets tangibility & TAG & (tangible assets + stocks)/total assets & + \\
\hline Size & TAL & Log (total assets) & - \\
\hline Risk & RSQ & The absolute value of the variation in net income & - \\
\hline Growth & CRO & Variation in total assets between t and t-1. & - \\
\hline Taxes & FIS & Taxes/Current income before tax & - \\
\hline Commercial debt & DFR & Commercial debt/total assets & - \\
\hline Business sector & SCT & $1=$ Industrial ; $0=$ retail & + \\
\hline
\end{tabular}

To verify the hypotheses formulated, the study starts with econometric tests using a basic model (Model 1) that has only firm size (TAL) and firm growth (CRO). The second model (model 2) tests the hypotheses on economic profitability (ROA) and financial profitability (ROE). To complete the econometric study, the paper tests the effect of the other variables on the total debt while adding one variable per model.

\section{Results}

\section{Descriptive Statistics}

The sample of 47 SMEs of the empirical study is divided into the commercial sector $(76.60 \%)$ and the industrial sector $(23.40 \%)$.

Table 3 gives a description of the variables used in our analysis. The total debt ratio (TDS) is on average 1,080 of total assets and it is a 5\% truncated is on average $92 \%$ of total assets. It ranges between $52.67 \%$ and 1.19 according to the first and third quartile. For the SMEs in the sample as a whole, we find that they achieved a low economic profitability (ROA) averaging $1.21 \%$, compared with $15.41 \%$ for the best-performing companies. Return on equity (ROE) averaged $9.76 \%$ and $75 \%$ of the companies had a profitability ratio of $50.95 \%$ or less. Tangible assets (TAG) are on average $43.77 \%$ of total assets. Tangible assets (TAG) are on average $43.77 \%$ of total assets. For the risk variable (RQS), we observe it shows high volatility (4.24). Companies with highly volatile net income 
can be perceived as riskier and use bank debt only to a limited extent. The average growth rate (CRO) of assets is $16.11 \%$ with a standard deviation of $50 \%$, indicating a significant difference among firms. A low growth rate can reduce the use of debt. SME in the sample pay less tax (FIS) it is on average $6.82 \%$, and $75 \%$ of SMEs pay less than $13.05 \%$ tax on their income. Commercial debt on average represents $30.23 \%$ of total assets.

Table 3. Descriptive Statistics

\begin{tabular}{|l|c|c|c|c|c|c|c|c|c|}
\hline & END & ROA & ROE & TAG & TAL & RSQ & CRO & FIS & DFR \\
\hline Mean & 1.0806 & 0.0121 & 0.0976 & 0.4377 & 5.6209 & 2.1352 & 0.1611 & 0.0682 & 0.3023 \\
\hline Sd & 1.1821 & 0.8173 & 2.9267 & 0.3396 & 0.8160 & 4.2460 & 0.4999 & 0.8582 & 0.5627 \\
\hline p25 & 0.5267 & -0.1806 & -0.0330 & 0.0838 & 4.9946 & 0.2124 & -0.1037 & -0.0137 & 0 \\
\hline p50 & 0.8231 & 0.0018 & 0.1595 & 0.4302 & 5.5782 & 1 & 0.0734 & 0 & 0.0587 \\
\hline p75 & 1.1980 & 0.1541 & 0.5095 & 0.7586 & 6.2740 & 2.4959 & 0.2993 & 0.1305 & 0.4304 \\
\hline
\end{tabular}

\section{Quality of Regression Results}

The Pearson correlation matrix between the independent variables (Table 4) shows that some associations are statistically significant but relatively low. This indicates the absence of serious multicollinearity problems among the exogenous variables.

Table 4. Pearson Correlation Matrix

\begin{tabular}{|l|c|c|c|c|c|c|c|c|}
\hline & ROA & ROE & TAG & TAL & RSQ & CRO & FIS & DFR \\
\hline ROE & $0.4260^{* *}$ & 1.0000 & & & & & & \\
\hline TAG & -0.0703 & -0.2558 & 1.0000 & & & & & \\
\hline TAL & -0.1590 & -0.1758 & 0.1896 & 1.0000 & & & & \\
\hline RSQ & -0.2187 & 0.1174 & 0.0331 & -0.0319 & 1.0000 & & & \\
\hline CRO & 0.0870 & -0.2736 & -0.0996 & -0.0419 & 0.1772 & 1.0000 & & \\
\hline FIS & 0.0805 & 0.0253 & 0.1222 & 0.2747 & -0.0596 & -0.0538 & 1.0000 & \\
\hline DFR & $-0.3256^{*}$ & -0.2161 & -0.0419 & -0.2125 & $0.4164 * *$ & 0.2448 & -0.1218 & 1.0000 \\
\hline SCT & -0.2184 & -0.0362 & 0.0555 & $0.3174 *$ & -0.0636 & -0.1731 & 0.2845 & 0.1271 \\
\hline
\end{tabular}

*Correlation is significant at the $5 \%$ level **Correlation is significant at the $1 \%$ level

Table 5 presents the empirical results of the multiple regression models. The different specifications which allow the variability of total debt (END) are explained by the previously selected exogenous variables. They have an explanatory capacity (Adj R-square) ranging from $2.11 \%$ (model 1) to $65.30 \%$ (model 8) and a good global significance (prob > F) at the 5\% threshold. However, the primary model (model 1) based on size (TAIL) and growth (CRO) is not significant.

The Durbin-Watson (D-W) statistic is around 2 in the different specifications and indicates the inexistence of error auto-correlation problems. The Tolerance and Variance Influence Factor (VIF) parameters are near 1, are less than the recommended limits (VIF <3.3). This result shows the absence of multicollinearity problems among exogenous variables, which confirms the results of the Pearson correlation matrix. All the tests converge towards identical results, which is a satisfactory indication of the different econometric specifications. 
Table 5. OLS Regression Output

\begin{tabular}{|l|c|c|c|c|c|c|c|c|}
\hline Variables & Model 1 & Model 2 & Model 3 & Model 4 & Model 5 & Model 6 & Model 7 & Model 8 \\
\hline C & 2.982 & 3.464 & 3.465 & 3.570 & 3.432 & 1.810 & 2.183 & 2.406 \\
\hline TAL & $(0.017)$ & $(0.002)$ & $(0.002)$ & $(0.001)$ & $(0.003)$ & $(0.041)$ & $(0.014)$ & $(0.006)$ \\
\hline- & -0.330 & -0.422 & -0.422 & -0.433 & -0.408 & -1.173 & -0.260 & -0.2813 \\
\hline CRO & $(0.125)$ & $(0.023)$ & $(0.027)$ & $(0.022)$ & $(0.038)$ & $(0.251)$ & $(0.092)$ & $(0.059)$ \\
\hline- & -2.982 & -0.0326 & -0.0335 & 0.1248 & 0.121 & -0.0806 & -0.0181 & - \\
\hline ROA & $(0.424)$ & $(0.916)$ & $(0.916)$ & $(0.708)$ & $(0.718)$ & $(0.751)$ & $(0.942)$ & - \\
\hline- & - & -0.919 & -0.918 & -1.038 & -1.029 & -0.821 & -0.7696 & -0.7905 \\
\hline ROE & - & $(0.000)$ & $(0.000)$ & $(0.000)$ & $(0.000)$ & $(0.000)$ & $(0.000)$ & $(0.000)$ \\
\hline- & - & 0.0759 & 0.0756 & 0.1091 & 0.110 & 0.158 & 0.1466 & 0.1400 \\
\hline TAG & - & $(0.198)$ & $(0.224)$ & $(0.101)$ & $(0.101)$ & $(0.003)$ & $(0.005)$ & $(0.002$ \\
\hline- & - & - & -0.0068 & 0.0973 & 0.115 & 0.240 & 0.240 & - \\
\hline RSQ & - & - & - & -0.0542 & -0.0547 & -0.118 & -0.1074 & -0.1061 \\
\hline- & - & - & - & $(0.160)$ & $(0.160)$ & $(0.000)$ & $(0.001)$ & $(0.001)$ \\
\hline FIS & - & - & - & - & -0.0824 & -0.088 & -0.1512 & - \\
\hline- & - & - & - & - & $(0.644)$ & $(0.511)$ & $(0.260)$ & - \\
\hline DFR & - & - & - & - & - & 1.340 & 1.2123 & 1.209 \\
\hline- & - & - & - & - & - & $(0.000)$ & $(0.000)$ & $(0.000)$ \\
\hline SCT & - & - & - & - & - & - & 0.5494 & 0.4809 \\
\hline- & - & - & - & - & - & - & $(0.062)$ & $(0.082)$ \\
\hline $\begin{array}{l}\text { R- } \\
\text { squared }\end{array}$ & 0.0636 & 0.3856 & 0.3856 & 0.4155 & 0.4187 & 0.6830 & 0.7119 & 0.6982 \\
\hline Adj R & 0.0211 & 0.3271 & 0.3106 & 0.3278 & 0.3144 & 0.6163 & 0.6418 & 0.6530 \\
\hline $\begin{array}{l}\text { F- } \\
\text { statistic }\end{array}$ & 1.50 & 6.59 & 5.15 & 4.74 & 4.01 & 10.24 & 10.16 & 15.43 \\
\hline Prob>F & 0.2353 & 0.0003 & 0.0009 & 0.0010 & 0.0021 & 0.0000 & 0.0000 & 0.0000 \\
\hline Max VIF & 1 & 1.41 & 1.54 & 1.77 & 1.77 & 1.82 & 1.85 & 1.60 \\
\hline D-W & 2.32 & 2.29 & 2.29 & 2.32 & 2.36 & 2.11 & 2.18 & 2.13 \\
\hline
\end{tabular}

\section{Discussion}

According to the results of the different econometric models (models 1 to 8), six variables in the final optimal model (model 8) influence the debt ratio of SMEs in a significant way. However, we found that three variables are not statistically significant in any of the models tested: growth rate (CRO) with irregular signs, asset tangibility (TAG), and taxes (FIS). Removing these variables in the final model (Model 8) increased the value of the adjusted $\mathrm{R}^{2}$ to $65,30 \%$. Based on these results, the study appears, unfortunately, unable to verify assumptions 4, 6, and 7 .

The size variable (TAL) is statistically significant and impacts negatively the total debt ratio. This result confirms hypothesis 1 along with the negative sign predicted by the Pecking Order Theory. This result can be explained by the fact that SMEs do not habitually have a diversified business portfolio that can reduce the volatility of cash-flows and require the use of debt. Moreover, these companies do not have the desirability of debt to avoid financial revealing and total loss of control of their enterprises'. Our results converge with those of Bourdieu and Colin- Sédillot (1993), Johnson (1997), Carpentier and Suret (1999), Adair and Adaskou (2011). 
Following the arguments of the Pecking Order Theory, economic profitability (ROA) has a negative and significant influence on the total debt. We can therefore confirm hypothesis 2 . This result can be explained by the fact that profitable SMEs prefer to use the resources generated by their assets. These resources allow the firm to maintain full control over ownership and they are less costly. Our results corroborate the findings of Titman and Wessels (1988), Harris and Raviv (1991), Colot and Croquet (2007), Fama and French (1999), Benkraiem (2010), and Rajan and Zingales (1995).

As for the return on equity (ROE) variable, the econometric results show that this variable is statistically significant and has a positive influence on the total debt ratio of SMEs. This confirms the Trade-off Theory predictions that profitable firms would have to take on debt to benefit from the tax-deductibility of interest charges. Besides, the existence of solid financial earnings can be interpreted by lenders as an indicator of the firm's financial health and its ability to honor its commitments within the meaning of the signal theory. Financial profitability makes it possible to reduce the information asymmetries that are an obstacle to SMEs' access to debt. Hypothesis 3 is confirmed again and our results are in accord with those of Hakmaoui and Yerrou (2013), Bourdieu and Colin-Sédillot (1993), and Johnson (1997).

The risk variable (RSQ) is statistically significant at the $1 \%$ level and negatively correlated with the total debt ratio. Hypothesis 5 of the negative relationship between earnings volatility and the debt ratio is confirmed. High earnings volatility makes it difficult to assess failure risk, which can cause more extensive problems of information asymmetry and difficulties in accessing debt (De Angelo and Masulis 1980). Our results are similar to those of Castanias (1983), Bradley et al. (1984), Bevan and Danbolt (2000), Benkraiem (2010) and Hakmaoui and Yerrou (2013).

The coefficient of the commercial debt variable (DFR) is positive and significant at the $1 \%$ level. An increase in the company's commercial debt is a reliable signal for lenders. That indicates the companies' ability to pay their loans. This result confirms the predictions of the Trade-Off Theory and invalidates the thesis of the Pecking Order Theory and Petersen and Rajan (1994) commercial debt is a less risky funding source and a substitute for the financial debt. Our hypothesis 8 cannot therefore be confirmed. Moreover, the empirical results are in line with those of Trabelsi (2006) and Adair and Adaskou (2011).

Activity sector (SCT) is a dummy control variable with industry as the reference variable. The coefficient associated with this variable is positive and significant at the $10 \%$ level. The empirical result confirms that SMEs in the industry sector are more indebted than those in the trade sector. Hypothesis 9 is verified and the sector influences the debt ratio of SMEs.

\section{Conclusion}

This paper examines the determinants of the capital structure of non-financial listed firms in the city of Meknes using a sample of 47 SMEs. This study was 
conducted using the econometric tool of the ordinary least squares estimation method (OLS). The econometric results show that 6 variables have a statistically significant effect on the total debt level of SMEs. These variables are: size, economic profitability, financial profitability, risk, commercial debt, and sector of activity. According to our assumptions, size, economic profitability, and risk are negatively associated with the total debt ratio. Contrary to our predictions, commercial debt is positively associated with the debt ratio. Financial profitability and industry sector are positively related to total debt ratios. The asset tangibility, growth, and tax variables suffer throughout the estimates from a lack of significance when other variables are integrated into the model. Moreover, statistical tests on the coefficients of the non-significant variables confirm that they are all zero.

\section{References}

Achy L, Rigar SM (2005) What determines financial structure in the Moroccan manufacturing sector? A firm level analysis. In $12^{\text {th }}$ Annual Conference, Economic Research Forum: Grand Hyatt, Caire, Egypte (1-17).

Adair P, Adaskou M (2011) Théories financières et endettement des PME en France : Une analyse en panel. (The financial theories and debt of SMEs in France: a panel analysis). Revue internationale P.M.E. : Économie et gestion de la petite et moyenne entreprise 24(3-4): 137-171.

Amraoui M, Jianmu Y, Bouarara K (2018) Firm's capital structure determinants and financing choice by industry in Morocco. International Journal of Management Science and Business Administration 4(3): 41-50.

Ang J (1992) On the theory of finance for privately held firms. The Journal of Entrepreneurial Finance 1(3): 185-203.

Baxter ND (1967) Leverage, risk of ruin and the cost of capital. The Journal of Finance 22(3): 395-403.

Beck T, Demirguc-Kunt A (2006) Small and medium-sized enterprises: access to finance as a growth constraint. Journal of Banking \& Finance 30(11): 2931-2943.

Benkraiem R (2010) Taille des entreprises et structure du capital: tests empiriques sur Euronext Paris. (Business size and capital structure: empirical tests on Euronext Paris). Management International 14(4): 115-124.

Besanko D, Thakor AV (1987) Collateral and rationing: sorting equilibria in monopolistic and competitive credit markets. International Economic Review 28(3): 671-689.

Bevan AA, Danbolt J (2002) Capital structure and its determinants in the UK - A decompositional analysis. Applied Financial Economics 12(3): 159-170.

Bourdieu J, Colin-Sédillot B (1993) Structure du capital et coûts d'information: le cas des entreprises françaises à la fin des années quatre-vingt. (Capital structure and information costs: the case of French companies at the end of the 1980s). Économie et Statistique 268(1): 87-100.

Bradley M, Jarrell GA, Kim EH (1984) On the existence of an optimal capital structure: theory and evidence. Journal of Finance 39(3): 857-878.

Carpentier, Cécile, and Jean-Marc Suret. (1999). Stratégies de financement des entreprises françaises: une analyse empirique (Financing strategies of french companies: an empirical analysis). Stratégies 99(Apr).

Castanias R (1983) Bankruptcy risk and optimal capital structure. The Journal of Finance 
38(5): 1617-1635.

Chen J (2004) Determinants of capital structure of Chinese-listed companies. Journal of Business Research 57(12): 1341-1351.

Chen J, Jiang C, Lin Y (2014) What determines firms' capital structure in China? Managerial Finance 40(10): 1024-1039.

Colot O, Croquet M (2007) La contribution de variables propres aux PME et à leur dirigeant dans l'explication de la structure financière des PME. (The contribution of specific variables for SMEs and their managers in the explanation of the capital structure of SMEs). La Revue des Sciences de Gestion 6(228): 61-72.

De Angelo H, Masulis R (1980) Optimall capital structure under corporate and personal taxation. Journal of Financial Economics 8(1): 3-29.

De Jong A, Veld C (2001) An empirical analysis of incremental capital structure decisions under managerial entrenchment. Journal of Banking \& Finance 25(10): 1857-1895.

Dine-dine N, El-Khamlichi B (2017) Financement et croissance des PME locales: Cas de la ville de Nador. (Financing and growth of local SMEs: the case of the city of Nador). Revue Du Contrôle de La Comptabilité et de l'Audit Décembre(3): 567-584.

Drobetz W, Fix R (2003) What are the determinants of the capital structure? Some evidence for Switzerland. University of Basel. WWZ/Department of Finance, Working Paper 4(03): 51-75.

Dubois M (1987) Les déterminants du niveau d'endettement des entreprises: les théories à l'épreuve des faits in finances et comptabilité. Ressources humaines. Approche globale de l'entreprise. Système industriel (The determinants of business debt levels: the facts in finance and accounting theories. Human resources. Global approach of the enterprise. Industrial system). Economies et Sociétés. Cahiers de l'ISMEA 21(6): $5-29$.

Fakhfakh H, Ben AR (2006) Les déterminants de la structure du capital des firmes tunisiennes : une étude à travers la théorie de Market Timing. (The determinants of the capital structure of Tunisian firms: a study across the theory of Market Timing). In Conférence Internationale en finance: Finance d'entreprise et finance de marché: quelles complémentarités? Pitiers, 1-25.

Fama EF, French KR (1999) The corporate cost of capital and the return on corporate investment. The Journal of Finance 54(6): 1939-1967.

Frank MZ, Goyal VK (2003) Testing the pecking order theory of capital structure. Journal of Financial Economics 67(2): 217-248.

Gaud P, Jani E (2002) Déterminants et dynamique de la structure du capital des entreprises suisses : une étude empirique. (Determinants and dynamics of the capital structure of Swiss companies: an empirical study). Retrieved from: http://archive-ouverte.unige. ch/unige:5810. [Accessed 18 March 2018.]

Hakmaoui A, Yerrou H (2013) Les déterminants de la structure financement: une étude empirique sur des entreprises marocaines. (Determinants of Financing Structure: An Empirical Study of Moroccan Firms). Journal of Economic 1(2): 83-93.

Harris M, Raviv A (1991) The theory of capital structure. The Journal of Finance 46(1): 297-355.

Jensen MC, Meckling WH (1976) Theory of the firm: managerial behavior, agency costs, and ownership structure. Journal of Financial Economics 3(4): 305-360.

Johnson SA (1997) An Empirical Analysis of the Determinants of Corporate Debt Ownership Structure. Journal of Financial and Quantitative Analysis 32(1): 47-69.

Kartobi SE (2013) Déterminants de la structure financière et réaction du marché boursier aux décisions de financement: cas des sociétés marocaines cotées à la bourse des valeurs de Casablanca. (Determinants of financial structure and stock market response to financing decisions: the case of moroccan companies listed on the 
casablanca stock exchange). Thèse de Doctorat en Sciences économiques et de gestion. Maroc-France: Université de Cadi Ayyad-Marrakech et de Nice Sophia Antipolis.

Kooyul J, Kim YC, Stulz RM (1996) Timing, investment opportunities, managerial discretion, and the security issue decision. Journal of Financial Economics 42(2): $159-85$.

Kremp É, Stöss E (2001) L'endettement des entreprises industrielles françaises et allemandes: des évolutions distinctes malgré des déterminants proches. (The indebtedness of French and German industrial companies: distinct trends despite similar determinants). Économie et Statistique 341(1): 153-171.

Leland HE, Pyle DH (1977) Informational asymmetries, financial structure, and financial intermediation. The Journal of Finance 32(2): 371-387.

Margaritis D, Psillaki M (2010) Capital structure, equity ownership and firm performance. Journal of Banking \& Finance 34(3): 621-632.

Messaoudi A, Binkkour M (2016) Comportement d'endettement des PME au Maroc : etat des lieux et facteurs explicatifs. (Debt behavior of SMEs in Morocco: current status and explanatory factors). International Journal of Innovation and Applied Studies 15(2): 395-405.

Miller M, Modigliani F (1958) The cost of capital, corporation finance and the theory of investment 48(3): 261-297.

Miller M, Modigliani F (1963) Corporate income taxes and the cost of capital: a correction. The American Economic Review 53(3): 433-443.

Myers SC (1977) Determinants of corporate borrowing. Journal of Financial Economics 5(2): 147-75.

Myers SC, Majluf NS (1984) Corporate financing and investment decisions when firms have informationthat investors do not have. Journal of Financial Economics 13(2): $187-221$.

OCDE (2002) Le rapport annuel de Organisation de Coopération et de Développement Economique (OCDE). (The annual report of the Organisation for Economic Cooperation and Development). Retrieved from: https://www.oecd.org/fr/presse/3852 8227.pdf. [Accessed 22 June 2019].

OCDE (2007) Le rapport annuel de Organisation de Coopération et de Développement Economique (OCDE). (The annual report of the Organisation for Economic Cooperation and Development). Retrieved from: https://www.oecd.org/fr/presse/385 28227.pdf. [Accessed 22 June 2019]

Oudgou M, Zeamari M (2018) Les déterminants de la structure financière des PME marocaine: cas de la ville de Meknès. (Determinants of the financial structure of Moroccan SMEs: the case of the city of Meknes). Finance \& Finance International 12(Jul): 1-25.

Petersen M, Rajan R (1994) The benefits of lending relationships: evidence from small business data. The Journal of Finance 49(1): 3-37.

Prowse SD (1990) Institutional investment patterns and corporate financial behavior in the United States and Japan. Journal of Financial Economics 27(1): 43-66.

Rafiki A (2008) Les déterminants de la structure financière: une analyse empirique de la situation marocaine. (Determinants of financial structure: an empirical analysis of the Moroccan situation). Revue Marocaine d'Administration Locale et de Développement (80): 113-139.

Rahj I (2016) Explication du recours à l'endettement: cas des PME marocaines. (Explanation of the recourse to indebtedness: the case of Moroccan SMEs). Thèse de doctorat en sciences de gestion. Casablanca, Maroc: Groupe ISCAE.

Rajan RG, Zingales L (1995) What do we know about capital structure? some evidence 
from international data. The Journal of Finance 50(5): 1421-1460.

Rajan R, Servaes H, Zingales L (2000) American finance association. The Journal of Finance 55(1): 35-80.

Riding A, Haines GH, Thomas R (1994) The Canadian small business-bank interface: a recursive model. Entrepreneurship Theory and Practice 18(4): 5-24.

Ross SA (1977) The determination of financial structure: the incentive-signalling approach. The Bell Journal of Economics 8(1): 23-40.

St-Pierre J (2004) La gestion du risque: comment améliorer le financement des PME et faciliter leur développement. (Risk management: how to improve SME financing and facilitate their development). Québec: Presses Universitaires de Québec.

Titman S, Wessels R (1988) The determinants of capital structure choice. The Journal of Finance 43(1): 1-19.

Trabelsi A (2006) Les déterminants de la structure du capital et les particularités du financement dans les PME: un étude sur données françaises. (The determinants of the capital structure and the particularities of financing in SMEs: a study based on French data). Thèse de Doctorat en Sciences de Gestion. Paris, France: Paris Dauphine EDOGEST.

Wessels R (2009) The determinants of capital structure choice. The Journal of Finance 43(1): $1-19$.

Yerrou H, Hakmaoui A (n.d.) La politique de signalement et condition de financement: Étude empirique sur un échantillon d'entreprises marocaines. (Signaling policy and financing conditions: an empirical study of a sample of Moroccan firms). Revue d'Evaluation et d'Anticipation Des Politiques Publiques (2): 129-150.

Zou H, Xiao ZJ (2006) The financing behavior of listed Chinese firms. The British Accounting Review 38(3): 239-258. 